\title{
En mann i 60-årene med akutt hodepine
}

\author{
Hodepine er et vanlig symptom. Oftest dreier det seg om tilstander \\ som migrene eller tensjonshodepine. Ved hyperakutt hodepine der lege \\ oppsøkes, har ca. $1 \%$ av pasientene subaraknoidalblødning. Denne \\ kasuistikken illustrerer at andre sjeldne, men livsfarlige tilstander kan \\ debutere med hyperakutt hodepine.
}

\author{
Øivind Torkildsen \\ ofto@helse-bergen.no \\ Nevrologisk avdeling

\section{Rafael Alexander Leiva} \\ Infeksjonsmedisinsk seksjon \\ Medisinsk avdeling \\ Shashi Gulati \\ Klinikk for hode/hals \\ $\emptyset$ re-nese-hals-avdelingen

\section{Gunnar Moen} \\ Radiologisk avdeling \\ Frode Svendsen \\ Nevrokirurgisk avdeling \\ Haukeland universitetssykehus
}

En mann i 60-årene tok kontakt med legevaktlege på grunn av hyperakutt intens hodepine som hadde oppstått i forbindelse med et tungt løft. Pasienten var fra tidligere frisk, bortsett fra astma og flere episoder med bihulebetennelse. Legevaktlege mistenkte subaraknoidalblødning, og pasienten ble innlagt på nevrokirurgisk avdeling. Ved ankomst i akuttmottak hadde pasienten kraftig, global hodepine. Han var i tillegg kvalm og lyssky. Ved klinisk undersøkelse ble det funnet normal nevrologisk status og normalt bevissthetsnivå. Han hadde lett forhøyet blodtrykk på 150/80 mm Hg, regelmessig puls på 68 slag/minutt og temperatur $37^{\circ} \mathrm{C}$. Blodprøvene tatt ved innkomst viste $C$-reaktivt protein (CRP) og leukocytter innenfor normalområdet.

På grunn av den hyperakutte hodepinen og betydelige smerter mistenkte vakthavende nevrokirurg at det dreide seg om en subaraknoidalblødning.

Cerebral CT og CT-angiografi like etter innleggelsen viste ikke tegn til blødning, men man fant på høyre side et intrakavernøst carotisaneurisme med diameter på $10 \mathrm{~mm}$ og en beineroderende prosess i sfenoidalsinus og clivus (fig 1, fig 2). MR-undersøkelse av hodet med og uten kontrast bekreftet et aneurisme $i$ mediale del av sinus cavernosus på høyre side og beindestruksjon $i$ samme område (fig 3 ).

MR-undersøkelsen og funnet av beindestruksjon ga mistanke om en kronisk sinusitt i sfenoidalsinus, og kombinasjonen av beindestruksjon og aneurisme kunne tyde på mulig aspergillusinfeksjon med mykotisk aneurisme på a. carotis interna i skallebasis. Beindestruksjon i sfenoidalsinus er forbundet med stor fare for ekstrem epistaxis, og vi kjenner til dødsfall som følge av epistaxis via sfenoidalsinus fra et tilsvarende aneurisme.

Følgende differensialdiagnoser ble overveid:

- Infeksjon og tilfeldig påvist aneurisme

- Kreft og tilfeldig påvist aneurisme

- Infeksjon og infeksiøst aneurisme

- Infeksjon og pseudoaneurisme (hull i arterien, men omkringliggende vev stopper blødning)

Infeksjonsmistanken var stor, og tre dager etter innleggelsen ble det derfor tatt en navigasjonsveiledet biopsi fra patologisk vev isfenoidalsinus. Pasientens hodepine hadde gitt seg noe, og det var ingen endring $i$ be-



Figur 1 CT ved innkomst av pasienten. Man ser en større eroderende prosess (pil) i høyre del av sfenoidalsinus, med beindestruksjon i clivus vissthet. Han hadde heller ikke feber eller stigende infeksjonsvariabler. Vi valgte derfor å la være å starte opp med antibiotika eller antimykotisk behandling før prøvetakingen var foretatt. Under biopsitakingen ble det ikke sett noen tydelige patologiske forandringer, men det ble tatt tre vevsbiter fra området som radiologisk viste beindestruksjon. Materialet ble sendt til dyrking og histologisk undersøkelse.

Dagen etter transsfenoidal prøvetaking $i$ narkose fikk pasienten akutt forverring av hodepinen, og det ble tatt en ny cerebral CT og CT-angiografi (fig 4). Den viste at den patologiske prosessen i sfenoidalsinus hadde ekspandert og at aneurismet hadde økt $i$ størrelse til $16 \mathrm{~mm}$ i diameter.

Den akutte forverringen av smertene skyldtes sannsynligvis en størrelsesøkning av aneurismet og derved påvirkning av nervestrukturer i sinus cavernosus. Vi ble nå overbevist om at pasienten hadde en infeksiøs prosess med utgangspunkt i sfenoidalsinus som destruerte a. carotis interna og ga et pseudoaneurisme. Det forelå absolutt indikasjon for å eliminere aneurismetilstanden for å forhindre en katastrofal epistaxis. På grunn av den pågående infeksjonen og sannsynlig pseudoaneurisme fant vi det ikke mulig å gjennomføre coilbehandling bak stent $\mathrm{i}$ det infiserte området. Det ble vurdert å gjøre eliminasjon av aneurismet ved «trap ligation», det vil si avstengning av a. carotis interna både proksimalt og distalt for aneurismet på den aktuelle høyre siden. Dette forutsatte at pasientens

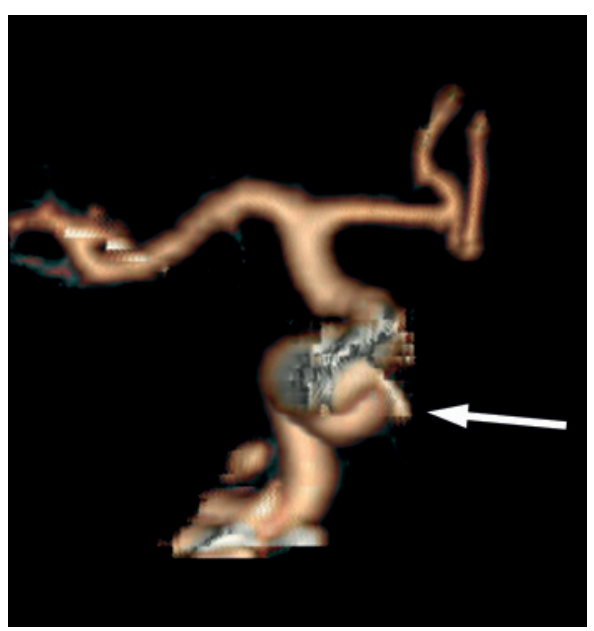

Figur 2 CT-angiografi tatt ved innkomst. Pseudoaneurisme på a. carotis interna (pil) 
høyre hjernehalvdel kunne få tilfredsstillende tilførsel fra venstre a. carotis interna.

Arteriell cerebral angiografi med kontrastinjeksjon på venstre side og kompresjon av a. carotis interna på høyre side viste at det ikke var overgang av blod fra venstre carotis til høyre hjernehalvdel via a. communicans anterior. Pasienten ville derfor ikke tåle okklusjon av a. carotis interna på den aktuelle høyre siden. Transkranial doppler bekreftet disse funnene. Videre viste arteriell angiografi at aneurismet var blitt dobbelt så stort på tre døgn (fig 5).

Pasienten ble betraktet som svært ustabil ettersom aneurismet ekspanderte, og man fryktet en fatal blødning. Siden det ikke var mulig å okkludere a. carotis interna på høyre side, anså man det som nødvendig at aneurismet ble fjernet med «trap ligation» - etter anleggelse av en cerebral bypass med v. saphena transplantat fra høyre a. carotis communis på halsen til intrakranial a. carotis interna distalt for klemmepåsetting.

Bypassoperasjonen ble gjennomført uten peroperativ avstenging under transplantatpåsying med såkalt ELANA-teknikk (Excimer Laser-Assisted Nonocclusive Anastomosis) (1). Dette er en ny metode som er etablert med det formål å koble bypasstransplantat til en større intrakranial arterie uten stans i blodforsyningen. Denne metoden blir i dag ikke utført i Norge. Sisteforfatteren fulgte derfor pasienten til utlandet der vi to dager etter overflyttingen gjennomførte «trap ligation» av aneurismet etter at cerebral bypass hadde sikret høyre hjernehalvdels blodforsyning. Postoperativ angiografi tatt like etter operasjonen viste at bypasstransplantatet dessverre tromboserte, og reoperasjon, som ble forsøkt nattetid, kunne ikke reetablere blodforsyningen. Pasienten utviklet betydelig hypoperfusjon av høyre hjernehalvdel. CT og MR tatt påfølgende dag viste uttalte infarktforandringer $i$ høyre hemisfære.

Pasienten har fått et betydelig sekvele med uttalt venstresidig hemiparese og tretthet, men det forventes fortsatt bedring av tilstanden ved rehabilitering nå to måneder etter at infarktet oppsto. Histopatologisk undersøkelse av preparat fra sfenoidalsinus viste tegn til inflammasjon, men ikke tegn til soppvekst. Verken dyrking eller polymerasekjedereaksjon (PCR) påviste tegn til aspergillus- eller candidainfeksjon. Imidlertid var det rikelig vekst av gule stafylokokker i biopsimaterialet.

\section{Diskusjon}

Hyperakutt hodepine er selve kardinalsymptomet på subaraknoidalblødning (2). Med hyperakutt hodepine mener man en eksplosiv, intens smerte, som utvikler seg til maksimal intensitet i løpet av sekunder til noen få minutter. Dette er en alvorlig diagnose med høy dødelighet, og hyperakutt hodepine bør derfor betraktes som subaraknoidalblødning inntil dette er avkreftet $(3,4)$. I engelsk litteratur bruker man ofte begrepet «thunderclap headache» om denne typen hodepine (5). En rekke andre tilstander kan også debutere med et liknende symptombilde (6). Det er ofte ikke mulig å skille disse tilstandene fra subaraknoidalblødning ut fra sykehistorien alene, og det er derfor svært viktig at pasientene legges inn akutt for nærmere utredning.

Hos vår pasient var den akutte hodepinen forårsaket av et infeksiøst aneurisme/pseudoaneurisme og osteomyelitt forårsaket av gule stafylokokker som følge av en kronisk bihulebetennele i sfenoidalsinus. Pasienten ble behandlet for infisert aneurisme og osteomyelitt i tilstøtende bein. Samlet behandlingstid med antibiotika bør være minimum åtte uker, men vi valgte hos denne pasienten å fortsette behandlingen $\mathrm{i}$ totalt seks måneder på grunn av det svært sårbare infeksjonsfokuset og høy risiko for pasienten ved manglende tilheling.

Uttrykket mykotisk aneurisme er tradisjonelt blitt brukt til å beskrive alle aneurismer som forårsakes av mikroorganismer. I den nevrokirurgiske litteraturen foretrekker man imidlertid ofte å bruke den mer presise betegnelsen infeksiøse aneurismer. Denne typen aneurismer er sjeldne og representerer mellom $1-5 \%$ av symptomatiske intrakraniale aneurismer (7). Det typiske kliniske debutsymptomet ved denne tilstanden er, som ved subaraknoidalblødning, akutt hodepine, forårsaket av ruptur av aneurismet (8). Det er rapportert høy mortalitet for denne tilstanden, fra $30 \%$ for urupturerte aneurismer opp til $80 \%$ ved ruptur. Den vanligste årsaken til denne typen aneurismer er bakteriell endokarditt (65\%), intravenøst stoffmisbruk $(6,3 \%)$, bakteriell meningitt $(5,2 \%)$ og dårlig tannhygiene (4,2\%) (8).

Som vår kasuistikk viser, kan også andre vanligvis godartede tilstander gi opphav til denne typen aneurismer. I vårt tilfelle hadde altså en kronisk bihulebetennelse ledet til osteomyelitt i sfenoidalsinus. På grunn av den korte avstanden fra sfenoidalsinus til a. carotis interna hadde denne tilstanden igjen gitt opphav til det infeksiøse aneurismet.

De fleste tilfellene med infeksiøse aneurismer skyldes bakterielle infeksjoner, særlig med gule stafylokokker og streptokokker. Det er imidlertid også blitt rapportert denne typen aneurismer forårsaket av infeksjoner med Aspergillus, Candida, Salmonella, Pseudomonas og tuberkulose (9). Aneurismene dannes ved at arterieveggen degenereres på grunn av infeksjonen. Infeksjonen medfører infiltrasjon av polymorfonukleære celler $\mathrm{i}$ både media- og adventititalagene i blodåren, med spredning gjennom muscularislaget. Dette gir igjen en proliferasjon av intima og destruksjon av indre elastiske lamina. Den hydrostatiske pulsasjonen mot den infiserte karveggen medfører så at aneurismet kanskje sprekker eller øker i størrelse (8).



Figur 3 MR tatt like etter innkomst. Sfenoidal sinusitt, osteomyelitt i clivus og aneurisme midt i lesjonen (pil). Aneurismet som vises kulerundt $110 \mathrm{~mm}$ i diameter), vokste ved to etterfølgende angiografiundersøkelser

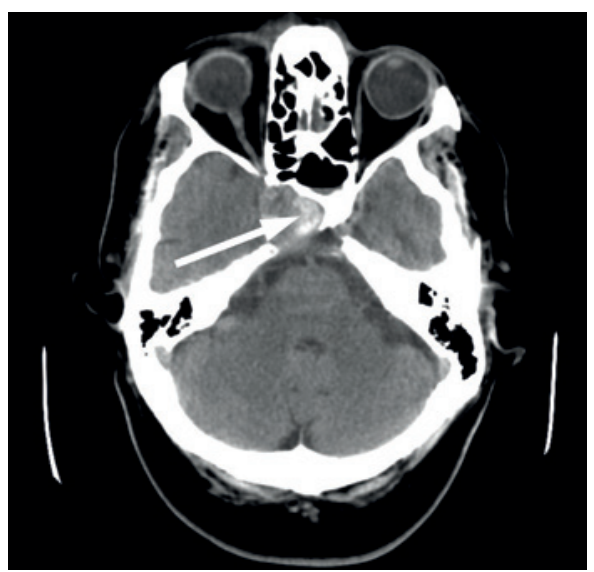

Figur 4 CT tatt like etter hyperakutt forverring av hodepineplagene. Den patologiske prosessen i sfenoidalsinus og clivus (pill har ekspandert i anterior retning. Aneurismet har også økt i størrelse og måler nå $16 \mathrm{~mm}$

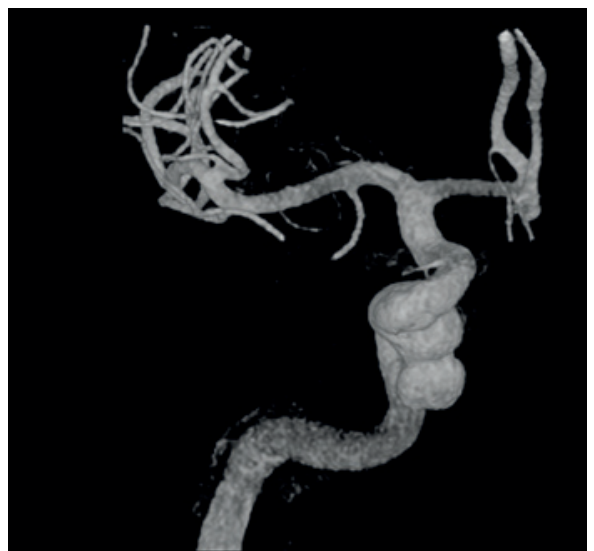

Figur 5 Angiografi tatt preoperativt for å kartlegge aneurismet og blodtilførselen til hiernen. Denne viste et stort pseudoaneurisme på a. carotis interna. I tillegg fant man ingen blodstrøm til kontralateral side fra venstre a. carotis interna 
Behandlingen av infeksiøse aneurismer er omdiskutert (10). Det foreligger ingen randomiserte studier over hvilke behandlingsmetoder som er mest effektive, og behandlingen må derfor individualiseres. Ved små, urupturerte aneurismer kan man forsøke antibiotikabehandling. Det er blitt rapportert tilbakegang av aneurismer på opptil $10 \mathrm{~mm}$ med kun medikamentell behandling, og en mer konservativ tilnærmingsmåte vil særlig være aktuelt ved multiplisitet, små aneurismer og vanskelig lokalisasjon (10). Ved ruptur er det derimot svært høy mortalitetsrisiko ved denne typen aneurismer.

Hos vår pasient var det tydelig symptomatisk vekst av aneurismet under oppholdet, og det ble besluttet at kirurgisk behandling derfor var nødvendig. Inngrepet ble ytterligere komplisert av at han ikke hadde noen kollateralsirkulasjon. Pasienten har fått et betydelig sekvele etter operasjonen som ble gjennomført. Det er derfor naturlig å stille spørsmål ved om andre metoder for eliminasjon av aneurismet kunne ha bidratt til et bedre postoperativt forløp. De to vanligste metodene for eliminasjon av infeksiøse aneurismer er nevroradiologisk intervensjon (coiling) eller kirurgisk klipsligatur. Det er vist i flere kasuistikker at coiling kan være en god behandlingsmetode for infeksiøse aneurismer (10). Ofte må disse behandles ved at tilførende arterie stenges av på den ene eller begge sidene av aneurismet. Coilbehandling eller klipsligatur av selve aneurismesekken med bevart karstruktur er sjelden mulig. På grunn av den manglende kollateralsirkulasjonen var det ikke mulig med nevroradiologisk intervensjon da vi vurderte at den hurtig voksende aneurismesekken måtte representere et pseudoaneurisme, altså et aneurisme uten veggstruktur. Infeksiøst aneurisme uten hals og uten sikker veggstruktur umuliggjorde coilbehandling av selve aneurismesekken. Avledningsstent (flow-diverting stent) ble også vurdert, men forkastet grunnet de infeksiøse forholdene og det faktum at en slik stent ikke ville gi umiddelbar beskyttelse mot en katastrofal blødning. På vitalindikasjon valgte vi derfor behandling med bypass og «trap ligation», som vi anså som den eneste tenkelige behandlingen for umiddelbar sikring av aneurismet, og med en god mulighet for at pasienten skulle bli helt frisk.

Infeksiøse aneurismer er en velkjent komplikasjon til endokarditt. Denne kasuistikken illustrerer at også andre relativt banale infeksjoner noen ganger kan lede til alvorlige, og noen ganger livstruende, følgetilstander.

Pasienten har gitt samtykke til at artikkelen blir publisert.

\section{Øivind Torkildsen (f. 1979)}

er postdoktor og lege i spesialisering ved Nevrologisk avdeling, Haukeland universitetssykehus.

Forfatter har fylt ut ICMJE-skjemaet og oppgir ingen interessekonflikter.

\section{Rafael Alexander Leiva (f. 1963)}

er spesialist $\mathrm{i}$ infeksjonsmedisin og overlege ved Infeksjonsseksjonen, Medisinsk avdeling, Haukeland universitetssykehus.

Forfatter har fylt ut ICMJE-skjemaet og oppgir ingen interessekonflikter.

\section{Shashi Gulati (f. 1956)}

er overlege ved Klinikk for hode/hals, Ørenese-hals-avdelingen, Haukeland universitetssykehus. Han har spesialkompetanse innen endoskopisk kirurgi i nese og bihuler og skallebasiskirurgi.

Forfatter har fylt ut ICMJE-skjemaet og oppgir ingen interessekonflikter.

\section{Gunnar Moen (f. 1958}

er spesialist i radiologi, med subspesialitet innen nevroradiologi. Han er overlege for Nevroradiologisk seksjon, Radiologisk avdeling, Haukeland universitetssykehus.

Forfatter har fylt ut ICMJE-skjemaet og oppgir ingen interessekonflikter.
Frode Svendsen (f. 1962)

er fagansvarlig for vaskulær nevrokirugi og assisterende avdelingssjef for Nevrokirurgisk avdeling. Haukeland universitetssykehus.

Forfatter har fylt ut ICMJE-skjemaet og oppgir ingen interessekonflikter.

\section{Litteratur}

1. Langer DJ, Van Der Zwan A, Vajkoczy P et al.

Excimer laser-assisted nonocclusive anastomosis. An emerging technology for use in the creation of intracranial-intracranial and extracranial-intracranial cerebral bypass. Neurosurg Focus 2008; $24:$ E6

2. Edlow JA, Malek AM, Ogilvy CS. Aneurysmal subarachnoid hemorrhage: update for emergency physicians. J Emerg Med 2008; 34: 237-51.

3. Hoddevik GH, Bjørang G. Oversett subaraknoidalblødning og forsvarlighet. Tidsskr Nor Laegeforen 2005; 125: 61-2.

4. Perry JJ, Stiell IG, Sivilotti ML et al. High risk clinical characteristics for subarachnoid haemorrhage in patients with acute headache: prospective cohort study. BMJ 2010; 341 (oct28 1): c5204.

5. Schwedt TJ, Matharu MS, Dodick DW. Thunderclap headache. Lancet Neurol 2006; 5: 621-31.

6. Bø SH, Bråthen G. Dietrichs E et al. Akutt hodepine-diagnostiske overveielser. Tidsskr Nor Laegeforen 2000; 120: 3551-5

7. Nakahara I, Taha MM, Higashi T et al. Different modalities of treatment of intracranial mycotic aneurysms: Report of 4 cases. Surg Neurol 2006 66: 405-9, discussion 409-10

8. Ducruet AF, Hickman ZL, Zacharia BE et al. Intracranial infectious aneurysms: a comprehensive review. Neurosurg Rev 2010: 33: 37-46.

9. Kannoth S, Thomas SV. Intracranial microbial aneurysm (infectious aneurysm): current options for diagnosis and management. Neurocrit Care 2009; 11: 120-9

10. Peters PJ, Harrison T, Lennox JL. A dangerous dilemma: management of infectious intracranial aneurysms complicating endocarditis. Lancet Infect Dis 2006; 6: 742-8.

Mottatt 5.1. 2011, første revisjon innsendt 8.3. 2011, godkjent 23.6. 2011. Medisinsk redaktør Lars Frich. 